\title{
ANALISIS PENGARUH KETERBUKAAN EKONOMI TERHADAP PERTUMBUHAN EKONOMI (STUDI KASUS: ASEAN TAHUN 2007 - 2017)
}

\author{
Rahmi Nuraini P.P. ${ }^{1}$, Drs. Y. Bagio Mudakir ${ }^{2}$ \\ Departemen IESP Fakultas Ekonomika dan Bisnis Universitas Diponegoro \\ Jalan Prof. Soedarto SH Tembalang, Semarang \\ rahminuraini96@gmail.com
}

\begin{abstract}
The era of globalization demands an increasingly broad economic openness from every country in the world, both openness in foreign trade (trade openness) and openness to the financial sector. In theory, economic openness benefits all countries involved. The advantages of trade openness include opening up wider market access to achieving higher levels of efficiency and economic competitiveness, as well as opportunities for greater employment. Openness in the financial sector can encourage the entry of foreign capital (capital inflow), and accelerate the occurrence of capital accumulation and technology transfer. This study aims to analyze the effect of economic openness on economic growth in ASEAN (Indonesia, Malaysia, Singapore, Thailand, Philippines, Vietnam, Brunei Darussalam, Cambodia) for the period 2000 - 2017. This study uses panel data regression analysis with a fixed effect approach.

The method in this study uses quantitative research by conducting hypothesis testing. The data used are secondary data from ASEAN countries in 2007-

2017 by looking at publications at the World Bank. This study uses panel data, where the panel data is a combination of cross section and time series data. The analytical tool used is panel data regression analysis using the Eviews 9 program. Then the best panel data regression model is estimated.

From the stages of analysis carried out, the results of data analysis showed that the results of the panel data estimation selected the best model were Fixed Effext Model (FEM). Hypothesis testing of the results of the Trade Openness (TO) and Foreign Direct Investment (FDI) model have a positive and significant effect on ASEAN Economic Growth $(G)$, while the government expenditure variable (GOV) has no significant positive effect. The inflation variable (INF) has no effect on economic growth.
\end{abstract}

Keywords: Economic Openness, Economic Growth, FDI, Government Expenditures, Inflation

\section{PENDAHULUAN}

Perbedaan kandungan sumber daya alam, sumber daya manusia, iklam maupun teknologi mengharuskan setiap negara menjalin hubungan ekonomi. Hubungan ekonomi mencakup pertukaran output, tenaga kerja, modal dan teknologi 
dari setiap negara (Herawati, 2016). Selain itu globalisasi juga menjadi tantangan bagi hampir semua negara di dunia dengan menuntut adanya keterbukaan ekonomi yang semakin luas. Perekonomian negara yang melakukan hubungan ekonomi dengan negara lain disebut sebagai perekonomian terbuka. Negara dengan perekonomian terbuka adalah negara yang melakukan kegiatan ekspor-impor barang atau jasa serta meminjam atau memberikan pinjaman pada pasar modal dunia. (Mankiw, 2005).

Keterbukaan ekonomi dapat memberikan peluang untuk mengekspor barang yang faktor produksinya menggunakan sumber daya berlimpah dan mengimpor barang yang faktor produksinya langka atau mahal jika diproduksi di dalam negeri. Menurut teori pertumbuhan ekonomi modern, keterbukaan ekonomi diyakini dapat mendorong pertumbuhan ekonomi suatu negara. Keterbukaan ekonomi dapat memberikan peluang untuk mengekspor barang yang faktor produksinya menggunakan sumber daya berlimpah dan mengimpor barang yang faktor produksinya langka atau mahal jika diproduksi di dalam negeri. Menurut teori pertumbuhan ekonomi modern, keterbukaan ekonomi diyakini dapat mendorong pertumbuhan ekonomi suatu negara.

Menurut penilitian dari Nowbutsing (2014) mengatakan bahwa keterbukaan merupakan sarana untuk mempromosikan pertumbuhan melalui penelitian dan pengembangan serta akses pasar yang lebih luas. Lebih jauh Zeren dan Ari (2013) memaparkan bahwa negara yang insentif melakukan perdagangan internasional dalam artian mampu melakukan ekspor pada barang yang memiliki keunggulan komparatif dan melakukan impor pada barang yang dibutuhkan mendorong proses produksi jangka panjang yang akan membawa negara tersebut dalam laju pertumbuhan dan pembangunan ekonomi yang positif dan berkelanjutan.

Meski begitu, penelitian dari Bibi (2014) defisit neraca perdagangan akibat dari aktivitas perdagangan membuat keterbukaan ekonomi tidak berpengaruh terhadap pertumbuhan ekonomi. Dreher (2006) keterbukaan ekonomi menurunkan standar sosial dan lingkungan, meningkatnya tingkat kemiskinan pada negara berkembang dan meningkatnya krisis keuangan di suatu negara. Hal-hal tersebut merupakan hambatan dari keterbukaan ekonomi terhadap pertumbuhan ekonomi, sehingga dampak positifnya tidak terasa.

Adanya perbedaan fenomena-fenomena dari beberapa penilitian mendorong penelitian ini untuk membahas hal yang serupa. Negara-negara berkembang mulai membentuk liberalisasi ekonomi. Perdagangan dan investasi internasional mulai marak, hingga akhirnya tercipta keterbukaan ekonomi. Liberalisasi antar negara ini telah membuat keterbukaan ekonomi ASEAN dari sisi perdagangan. Hal ini bisa dilihat dari grafik perdagangan ekspor-impor ASEAN tahun 2007-2017 sebagai berikut: 
Gambar 1.1 Ekspor-Impor ASEAN Tahun 2007-2017

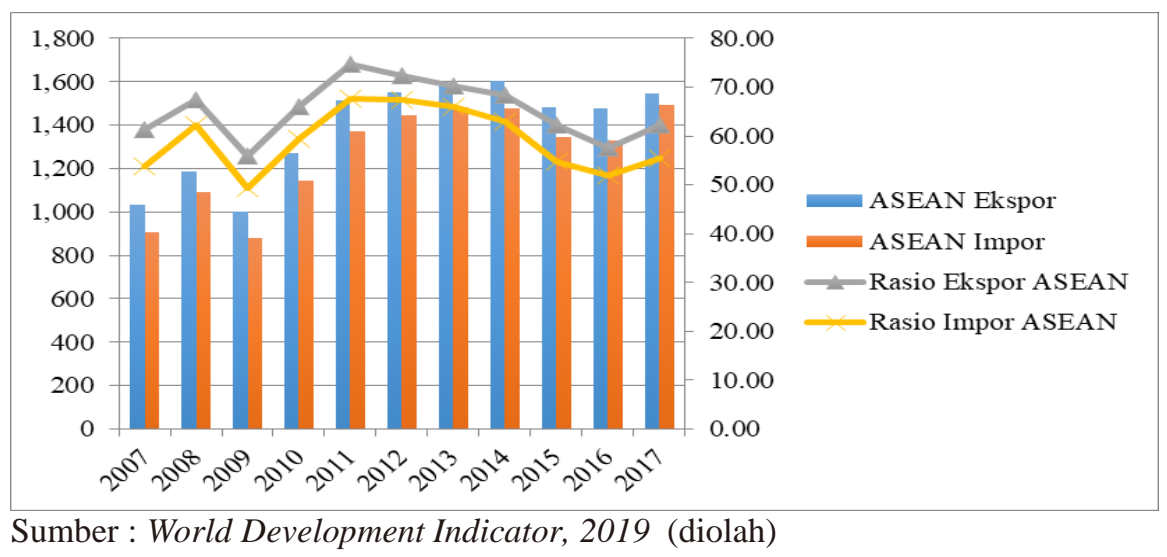

Pada gambar 1.1 terlihat bahwa baik berdasarkan nilai maupun rasio ekspor telah terjadi peningkatan. Peningkatan rasio ekspor per GDP ASEAN meningkat dari 61\% pada tahun 2007 menjadi 62\% pada tahun 2013. Dengan kata lain telah terjadi peningkatan keterbukaan perdagangan dari sisi ekspor masih sebesar $1 \%$. Meskipun rasio ekspor terlihat fluktuatif, namun pada dasarnya menunjukkan kecendurungan yang terus meningkat. Peran ASEAN terhadap perdagangan dunia juga dapat terlihat dari keterbukaan perdagangannya yang diukur berdasarkan rasio ekspor dan impor terhadap GDP atau trade openness. Trade openness (TO) merupakan jumlah nilai ekspor dan impor terhadap PDB, untuk menilai kinerja perdagangan suatu negara. Trade openness akan memberikan dampak positif terhadap GDP. Semakin besar nilai trade openness berarti semakin besar juga rasio keterbukaan ekonomi ASEAN. Hal tersebut juga mengartikan bahwa semakin besar juga kontribusi yang diberikan trade openness bagi GDP (Marbun, 2018).

Di antara negara - negara ASEAN, tingkat keterbukaan perdagangan paling tinggi terdapat di Singapura, seperti yang ditunjukkan pada Tabel 1.1 Menurut teori dasar perdagangan internasional, dimana setiap negara berusaha meningkatkan daya saing (competitiveness) untuk mendapatkan gains from trade (Amala \& Heriqbaldi, 2015). Barro (2003) menyatakan bahwa pertumbuhan ekonomi sangat erat hubungannya dengan keterbukaan perekonomian suatu negara, dimana perdagangan internasional akan memberikan dampak positif dan sigfikan terhadap pertumbuhan ekonomi.

Tabel 1. 1

Perkembangan Keterbukaan Perdagangan ASEAN 2013 - 2017

\begin{tabular}{|l|r|r|r|r|r|}
\hline & 2013 & 2014 & 2015 & 2016 & 2017 \\
\hline Indonesia & 48.64 & 48.08 & 41.94 & 37.44 & 39.54 \\
Malaysia & 142.72 & 138.31 & 133.55 & 128.64 & 135.92 \\
Singapura & 365.69 & 359.25 & 329.05 & 310.26 & 322.43 \\
Thailand & 133.41 & 131.80 & 125.90 & 122.17 & 122.80 \\
\hline
\end{tabular}


Jurnal Dinamika Ekonomi Pembangunan

https://ejournal.undip.ac.id/index.php/dinamika_pembangunan/index

\begin{tabular}{|l|r|r|r|r|r|}
\hline Filipina & 60.25 & 61.47 & 62.69 & 64.90 & 70.66 \\
Vietnam & 165.09 & 169.53 & 178.77 & 184.69 & 200.38 \\
Brunnei D & 110.94 & 99.37 & 84.90 & 87.32 & 85.18 \\
Kamboja & 130.05 & 129.61 & 127.86 & 126.95 & 124.89 \\
\hline
\end{tabular}

Sumber : World Development Indicator, 2019 (diolah)

Selain keterbukaan ekonomi dari sisi perdagangan, ASEAN juga memberikan akses pada keterbukaan dari sisi finansial. Winantyo et al. (2008) menyatakan bahwa dalam mewujudkan AEC (ASEAN Economic Community) berupa terjadinya keterbukaan perdagangan, investasi, dan tenaga kerja terampil maka dibutuhkan keterbukaan finansial. Keterbukaan finansial diperlukan untuk mendukung transaksi keuangan yang lebih efisien, sebagai salah satu sumber pembiayaan pembangunan, memfasilitasi perdagangan internasional, mendukung perkembangan sektor keuangan, dan akhirnya meningkatkan pertumbuhan ekonomi.

Melihat struktur perekonomian disetiap negara di dunia yang mulai menerapkan keterbukaan, menyebabkan perekomian negara berkembang dewasa ini tidak hanya terfokus pada aktivitas perdagangan saja, melainkan juga memperhatikan pergerakan invetasi asing, karena pada dasarnya perdagangan dan investasi asing merupakan dua komponen makroekonomi yang berperan sebagai mesin pertumbuhan (Sutawijaya dan Zulfahmi, 2010). (Hussin \& Saidin, 2017) pada analisis empirisnya mengenai perekonomian di beberapa negara berkembang ASEAN menyatakan bahwa pertumbuhan ekonomi di negara - negara berkembang ASEAN sebagian besar tidak hanya ditopang oleh keuntungan perdagangan, melainkan juga foreign direct investment (FDI).

Tabel 1.2

FDI Negara - Negara ASEAN tahun 2013 - 2017 (Dalam Persen)

\begin{tabular}{|l|rrrrr|}
\hline Negara & $\mathbf{2 0 1 3}$ & $\mathbf{2 0 1 4}$ & $\mathbf{2 0 1 5}$ & $\mathbf{2 0 1 6}$ & $\mathbf{2 0 1 7}$ \\
\hline Indonesia & 2.55 & 2.82 & 2.30 & 0.49 & 2.11 \\
\hline Malaysia & 3.49 & 3.14 & 3.33 & 4.54 & 3.02 \\
\hline Singapura & 21.18 & 22.32 & 23.21 & 23.97 & 19.65 \\
\hline Thailand & 3.79 & 1.22 & 2.22 & 0.74 & 1.75 \\
\hline Filipina & 1.37 & 2.02 & 1.93 & 2.72 & 3.21 \\
\hline Vietnam & 5.20 & 4.94 & 6.11 & 6.14 & 6.30 \\
\hline Brunnei D & 4.29 & 3.32 & 1.32 & 1.32 & 3.86 \\
\hline Kamboja & 12.29 & 10.30 & 9.42 & 11.43 & 12.57 \\
\hline
\end{tabular}

Sumber : World Development Indicator, 2018 (diolah)

Tabel 1.1 adalah tabel yang menunjukkan aliran FDI yang masuk ke masing masing negara ASEAN pada tahun 2013 - 2017. Aliran FDI ini juga digunakan sebagai indikator keterbukaan finansial dalam era globalisasi. Berdasarkan tabel diatas dapat diketahui bahwa negara Singapura merupakan penampil FDI yang paling besar hingga $23.97 \%$ di tahun 2016. Kemudian, jauh dibawahnya yaitu Kamboja (11.43\%), Vietnam (6.14\%), Malaysia (4.54\%), Filipina (2.72\%), Brunei (1.32\%), Thailand $(0.74 \%)$ dan yang terakhir Indonesia sebesar $0.49 \%$. 
Menurut teori pertumbuhan neoklasik bahwa FDI dapat menyalurkan dana untuk sektor - sektor produktif ekonomi yang kekurangan modal sehingga mampu meningkatkan pertumbuhan ekonomi dengan meningkatkan modal. Di sisi lain, pertumbuhan endogen menyatakan bahwa pertumbuhan jangka panjang suatu negara tidak hanya dipengaruhi oleh investasi fisik tapi juga tergantung pada efisiensi penggunaan investasi (Adhikary, 2011).

Penelitian dari Oyekele (2016) mengatakan bahwa keterbukaan ekonomi mempengaruhi pengeluaran pemerintah. Pengeluaran pemerintah merupakan alat fiskal yang kuat diantara kebijakan ekonomi yang lainnya. Dari teori juga membuktikan pengaruh besar pengeluaran pemerintah pada pertumbuhan ekonomi dan stabilisasi ekonomi. Berdasarkan penelitian dari Nowbutsing (2014) memasukkan variabel pengeluaran pemerintah untuk meneliti pertumbuhan ekonomi dalam era keterbukaan ekonomi. Hubungan antara pertumbuhan ekonomi dan pengeluaran pemerintah, atau lebih umumnya adalah ukuran dari sektor publik, menjadi obyek penting untuk dianalisis dan diperdebatkan (Maharani, 2014). Teori menunjukkan bahwa pengeluaran pemerintah dapat mendorong produksi dengan meningkatkan subsidi kepada produsen. Semakin besar pengeluaran pemerintah yang dilakukan akan menimbulkan multiplier effect terhadap perekonomian yang akan memberikan manfaat yang besar terhadap pertumbuhan ekonomi (Nowbutsing, 2014).

Tabel 1. 3

\section{Peran Pengeluaran Pemerintah Terhadap GDP Negara-Negara ASEAN Tahun} 2007-2017 (Dalam Persen)

\begin{tabular}{|l|r|r|}
\hline \multicolumn{1}{|c|}{ Negara } & \multicolumn{1}{|c|}{2007} & \multicolumn{1}{c|}{2017} \\
\hline Indonesia & 5.63 & 8.48 \\
Malaysia & 9.74 & 10.50 \\
Singapura & 8.44 & 11.34 \\
Thailand & 11.66 & 17.64 \\
Filipina & 7.88 & 11.69 \\
Vietnam & 4.40 & 8.31 \\
Brunei Darussalam & 19.98 & 23.83 \\
Kamboja & 4.98 & 6.25 \\
\hline
\end{tabular}

Sumber : World Development Indicator, 2018 (diolah)

Selama kurun waktu 2007-2017, pangsa penegluaran pemerintah terhadap GDP relatif stabil. Peran pengeluaran pemerintah terhadap pembentukan GDP pada tahun 2017 untuk negara Indonesia, Vietnam dan Kamboja tidak mencapai 10\%. Pemerintah merupakan pendukung dari pembangunan dan penunjang kegiatan pemerintahan serta peningkatan pelayanan yang secara langsung berkaitan dengan pembentukan modal untuk tujuan peningkatan produksi. 
Peran pemerintah untuk mendukung pengembangan ini terwujud dalam pengeluaran pemerintah. Pengeluaran pemerintah sebagai bentuk nyata dari campur tangan pemerintah dalam perekonomian telah menjadi objek penting untuk diteliti.

Faktor lain yang mempengaruhi pertumbuhan ekonomi pada era keterbukaan adalah inflasi. Keterbukaan ekonomi, yang diharapkan dapat meningkatkan kesejahteraan masyarakat, pada prinsipnya memang tidak hanya berpengaruh terhadap output, tetapi juga harga. Hal ini terjadi karena adanya konsekuensi (trade off) antara output dan inflasi. Pada sisi lain, ada suatu kebijakan otoritas moneter yang bertujuan menstabilkan perubahan harga, yaitu: Inflation Targeting Framework (ITF) Stabilitas inflasi ini penting dilakukan terkait dengan ekspektasi baik masyarakat maupu dan pemerintah. Hubungan tingkat inflasi terhadap pertumbuhan ekonomi yang dapat dilihat dari pernyataan (Azid, 2015) Tingkat inflasi yang rendah pada suatu negara menunjukkan lingkungan perekonomiannya stabil sehingga berdampak positif bagi pertumbuhan ekonomi. Namun jika tingkat inflasinya mengalami fluktuatif (mudah berubah), maka akan mempersulit atau memperlambat kenaikan pertumbuhan ekonomi suatu negara.

Tingkat inflasi berdasarkan hasil penelitian terdahulu dari (Pramasty, 2015) memiliki hubungan negatif terhadap pertumbuhan ekonomi di tujuh negara ASEAN, sedangkan menurut (Riyad, 2012) variabel tingkat inflasi tidak berpengaruh secara signifikan terhadap pertumbuhan ekonomi di enam negara ASEAN.

Gambar 1.2

Tingkat Inflasi ASEAN Tahun 2007 - 2017 (Dalam Persen)

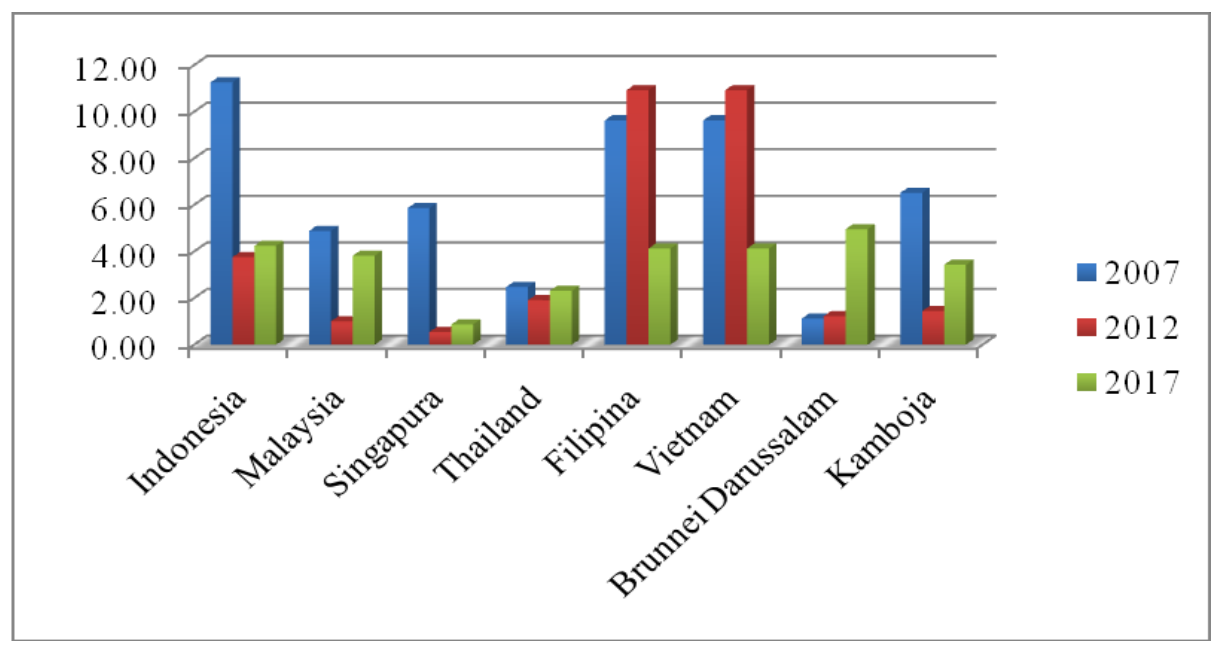

Sumber : World Development Indicator, 2018 (diolah)

Berdasarkan gambar diatas negara Indonesia mempunyai tingkat inflasi yang tinggi yaitu diatas $8 \%$. Selain itu, Vietnam dan Filipina mempunyai tingkat inflasi sebesar 9\%. Malaysia, Singapura, Thailand, Brunei dan Kamboja mempunyai rata rata tingkat inflasi yang rendah yaitu dibawah $4 \%$. Tingkat inflasi di Indonesia berdasarkan gambar 1.4 sanggat tinggi hal ini menunjukkan bahwa sistem pengendalian moneter dan fiskal negara Indonesia kurang terkendali. Tahun 2009 
tingkat inflasi Indonesia sekitar $9,78 \%$ berbanding dengan Singapura $6,52 \%$ artinya kebijakan keterbukaan ekonomi Singapura lebih stabil dan terkendali.

Berdasarkan paparan yang telah disampaikan di atas, terdapat banyak perdebatan bahwa pengaruh keterbukaan ekonomi terhadap pertumbuhan ekonomi. masih menjadi perdebatan. Oleh karena itu, untuk mengetahui pengaruh ang sesungguhnya dari keterbukaan ekonomi terhadap pertubuhan ekonomi terutama di wilayah ASEAN penelitian ini bertujuan untuk menganalisis apakah variabel tersebut berdampak pada pertumbuhan ekonomi.

\section{LITERATURE REVIEW}

\section{Teori Pertumbuhan Ekonomi}

Pertumbuhan ekonomi merupakan merupakan proses dimana terjadi kenaikan produk nasional bruto riil atau pendapatan nasional riil. Jadi perekonomian dikatakan tumbuh dan berkembang apabila terjadi pertumbahan output riil (Purnama, tanpa tahun). Pertumbuhan ekonomi dapat didefinisikan sebagai perkembangan barang dan jasa yang diproduksikan dalam masyarakat bertambah. Meningkatnya jumlah produksi disebabkan karena faktor produksi, inveestasi, tekonologi dan tenaga kerja (Sukirno, 2013). Perekonomian dianggap mengalami pertumbuhan apabila pendapatan riil masyarakat pada tahun tertentu lebih besar daripada pendapatan riil masyarakat tahun sebelumnya (Riyad, 2012). Indikator yang biasanya digunakan adalah tingkat pertumbuhan Gross Domestic Product (GDP) (Mankiw, 2007).

\section{Teori Pertumbuhan Ekonomi Klasik}

Teori ini pertama kali dikemukakan oleh Adam Smith melalui bukunya the Wealth of Nations pada tahun 1776. Kemudian teori ini dikembangkan lagi oleh tokoh - tokoh klasik lainnya seperti David Ricardo, Thomas R. Maltus dan JS Mill yang kemudian disebut sebagai teori pertumbugan ekonomi klasik. Teori pertumbuhan ekonomi klasik sangat mengutamakan azaz liberal atau laisssez faire, dimana segala aktivitas perekonomian diharapkan bebas tanpa ada campur tangan pemerintah (Susilowati, tanpa tahun).

\section{Teori Pertumbuhan Ekonomi Harrod Domar}

Pada teori pertumbuhan ekonomi menurut Harrod - Domar menekankan bahwa untuk mencapai tingkat steady growth pada suatu perekonomian terletak pada peran aktif investasi (Jhingan, 1983). Harrod dan Domar menjelaskan bahwa tingkat investasi pada suatu negara mampu memberikan kontribusi besar dalam mendorong laju pertumbuhan ekonomi, terutama di negara berkembang. Hal yang menjadi dasar pemikiran Harrod dan Domar bahwa instrument investasi memiliki dua peran besar pada perekonomian, yaitu sebagai sumber pendapatan dan modal untuk meningkatkan kapasitas produksi (Hashmi et al, 2012).

\section{Teori Pertumbuhan Ekonomi Solow}

Pada teori pertumbuhan ekonomi Solow, instrument teknologi lebih ditekankan sebagai komponen eksogen yang memiliki peran penting dalam mendorong pertumbuhan ekonomi, karena pada dasarnya teknologi bersifat pure public goods. 


\section{Teori Pertumbuhan Endogen}

Model pertumbuhan endogen berpandangan bahwa ilmu pengetahuan dan pengembangan teknologi memiliki peran yang lebih luas disamping modal. Ilmu pengetahuan dan teknologi mampu menjadi input utama untuk mendorong laju pertumbuhan ekonomi yang diinginkan dengan asumsi teknologi bukan hanya bersifat eksogen melainkan endogen (Erikson, 1995). Dalam era keterbukaan atau globalisasi merupakan peluang bagi negara nerkembang untuk mendorong laju pertumbuhan ekonomi sesuia prinsip pada model pertumbuhan endogen. Jika suatu negara menerapkan tingkat keterbukaan ekonomi meningkatkan peluang negara tersebut untuk memperoleh percepatan laju pertumbuhan ekonomi sesuai implikasi model pertumbuhan endogen (Prijambodo, 1995).

\section{Keterbukaan Ekonomi}

Keterbukaan ekonomi merupakan ukuran kebijakan untuk mengatur arus barang dan jasa serta arus modal secara internasional baik dalam bentuk membatasi maupun memperlonggar hubungan internasional antarnegara. Penerapan kebijakan ekonomi bertujuan untuk mewujudkan perkembangan dan pergerakkan perekonomian yang lebih baik. Dalam keterbukaan ekonomi terdapat dua arus pergerakan internasional. Pertama, keterbukaan perdagangan atau trade openness yang mengatur pergerakan arus barang dan jasa. Kedua, untuk mengatur arus internasional adalah financial openness (Yanikkaya, 2003).

\section{Pengertian Investasi}

Investasi merupakan indikator makroekonomi yang berperan sebagai mesin pertumbuhan disamping perdagangan. Melihat peran investasi yang penting bagi perekonomian, menyebabkan para pengambil kebijakan menetapkan beberapa kebijakan penanaman modal secara konsisten dan berhati - hati sehingga modal nasional dapat terkendali dan laju pertumbuhan ekonomi jangka panjang dapat terwujud.

\section{Teori Perdagangan Internasional}

Merupakan interaksi pertukaran dan jasa oleh dua negara atau lebih melalui ekspor dan impor yang bertujuan untuk memperoleh keuntungan dari hasil spesialisasi produk atas keunggulan komparatif yang dimiliki oleh masing - masing negara (Alfin, et.al. 2008).

\section{Pengertian Pengeluaran Pemerintah}

Pengeluaran pemerintah sebagai salah satu komponen pengeluaran memiliki andil dalam mempengaruhi kondisi perekonomian suatu negara. Pemerintah bukan saja berfungsi untuk mengatur kegiatan perekonomian tetapi juga dapat mempengaruhi tingkat pengeluaran agregat dalam perekonomian. disatu pihak kegiatan pemerintah melalui pemungutan pajak akan mengurangi pembelanjaan agregat, tetapi disisi lain pajak tersebut dibelanjakan lagi oleh pemerintah dan selanjutnya akan meningkatkan pengeluaran agregat. Biasanya pemerintah membelanjakan dana melebihi pajak, dan langkah tesebut yang akan meningkatkan keseluruhan pembelanjaan agregat (Sukirno, 2013). 


\section{Stabilisasi Inflasi}

Inflasi merupakan gejala peningkatan harga secara umum dalam perekonomian secara terus - menerus. Dengan demikian tingkat inflasi adalah perubahan yang terjadi pada tingkat hara (Blanchard, 2004). Penyebab inflasi dengan pendekatan pasar riil atau pasar barang dibagi menjadi dua, yaitu yang disebabkan oleh kelebihan permintaan (demand pull inflation) dan yang disebabkan oleh kenaikan biaya produksi (cost push inflation).

\section{Hubungan Pertumbuhan Ekonomi dengan Keterbukaan Perdagangan}

Hubungan pertumbuhan ekonomi dengan keterbukaan perdagangan dapat dlihat dari berbagai pendapat antara lain menurut Clemens dan Williamsons (2002) yang melakukan penelitian dalam periode yang relatif lama. Mereka menemukan bahwa hubungan antara keterbukaan dan pertumbuhan menjadi signifikan hanya dalam periode sekarang yang berarti bahwa secara relatif ekonomi terbuka menjadi syarat untuk perdagangan internasional yang akan berdampak terhadap pertumbuhan ekonomi.

\section{Hubungan Pertumbuhan Ekonomi dengan FDI}

Hubungan FDI dengan pertumbuhan ekonomi telah dijelaskan oleh Syafaat Fachriza (2015) bahwa FDI berpengaruh signifikan terhadap pertumbuhan ekonomi di Indonesia selama periode 1984 - 2014. Adanya FDI yang masuk akan meningkatkan pertumbuhan ekonomi melalui peningkatan sumber daya manusia yang ahli dalam bidangnya, peningkatan infrastruktur untuk membantu pendistribusian, serta meningkatkan ekspor. Sementara menurut Octavianingrum (2015) investasi dalam peralatan modal tidak saja meningkatkan produksi tetapi juga kesempatan kerja. Dengan terbukanya kesempatan kerja yang lebih luas, maka tingkat pendapatan masyarakat bertambah.

Dengan demikian dapat disimpulkan bahwa kenaikan laju investasi meningkatkan pendapatan nasional. Oleh sebab itu investasi merupakan jalan keluar uatama dari masalah yang dihadapi negara berkembang dan merupakan kunci utama pertumbuhan ekonomi.

\section{Hubungan Pertumbuhan Ekonomi dengan Pengeluaran Pemerintah}

Hubungan pertumbuhan ekonomi dengan pengeluaran pemerintah dapat dilihat dari pernyataan Mankiw (2006) yang menyatakan bahwa nilai GDP merupakan nilai total pengeluaran setiap unit ekonomi dimana salah satunya adalah 
pengeluaran pemerintah. Semakin besar pengeluaran pemerintah yang dilakukan akan menimbulkan multiplier effect terhadap perekonomian yang akan memberikan manfaat yang besar terhadap pertumbuhan ekonomi.

\section{Hubungan Pertumbuhan Ekonomi dengan Inflasi}

Hubungan pertumbuhan ekonomi dengan inflasi dapat dilihat dari pernyataan Barro (1997) dalam penelitiannya yang menemukan efek negatif dari inflasi terhadap pertumbuhan ekonomi. Tingginya tingkat inflasi akan berdampak pada melambatnya pertumbuhan ekonomi, sebaliknya apabila pemerintah mampu mengendalikan inflasi pada level yang rendah maka efeknya adalah percepatn pertumbuhan ekonomi akan lebih mudah dicapai. Penelitian dari (Bibi, et al, 2012) menyatakan bahwa inflasi juga berhubungan negatif dengan pertumbuhan ekonomi di Pakistan.

\section{METODE PENELITIAN}

\section{A. Definisi Operasional}

Dalam penelitian ini, variabel dependen yang digunakan adalah pertumbuhan ekonomi/GDP (G), sedangkan variabel independennya adalah trade openness (TO), FDI, pengeluaran pemerintah (GOVEX) dan inflasi (INF).

1. Pertumbuhan Ekonomi $(G)$

Variabel pertumbuhan ekonomi yang digunakan adalah $G$ di lima negara ASEAN (Indonesia, Malaysia, Singapura, Thailand, Filipina, Vietnam, Brunei Darussalam dan Kamboja) selama tahun 2007 - 2017. Pertumbuhan GDP merupakan laju pertumbuhan ekonomi. Pengertian GDP riil ialah ukuran output ekonomi suatu negara per individu yang diukur dengan harga konstan. GDP riil merupakan hasil dari produk domestik bruto dibagi dengan populasi tengah tahun selama periode tertentu yang diukur menurut harga konstan 2010 (dalam US dollar). Data diperoleh dari World Bank yang dinyatakan dalam satuan persen pada tahun 2000 hingga 2017. Nilai variabel $\mathrm{G}$ dirumuskan sebagai berikut :

Keterangan

$$
\mathrm{G}=\frac{P D B t-(P D B t-1)}{P D B t-1} \times 100 \%
$$

\section{GDPt $\quad$ :Gross Domestic Product pada tahun t \\ GDPt-1 :Gross Domestic Product pada tahun t-1}

2. Keterbukaan Perdagangan / Trade Openness (TO)

Keterbukaan perdagangan merupakan ukuran keterbukaan perdagangan internasional yang diterapkan pada perekonomian suatu negara untuk mendorong pemenuhan barang. Pengukuran keterbukaan perdagangan dihitung berdasarkan jumlah dari ekspor dan impor dibagi dengan GDP. Data keterbukaan perdagangan diperoleh dari World Bank (Bibi et al, 2014)

\section{Foreign Direct Investment (FDI)}

FDI merupakan jumlah dari modal ekuitas, reinvestasi penghasilan, modal jangka panjang lainnya, dan modal jangka pendek seperti yang ditunjukkan dalam neraca pembayaran. Seri ini menunjukkan arus masuk bersih (arus masuk investasi baru dikurangi disinvestasi) dalam ekonomi pelaporan dari investor asing, dan dibagi oleh PDB. Data FDI yang digunakan dalam penelitian ini adalah data FDI net inflow dalam bentuk persen dan sumber data diambil dari publikasi World Bank. 


\section{Pengeluaran Pemerintah (GOVEX)}

Pengeluaran pemerintah dalam penelitian ini menggunakan total pengeluaran pemerintah dalam satuan persen di lima negara ASEAN selama tahun 2007-2017. Dalam penelitian ini juga pengeluaran pemerintah merupakan pendorong dari kegiatan riset dan pengembangan untuk menciptakan kemajuan teknologi (Purwanto, 2011). Sumber data diambil dari World Development Indicator (2018).

5. Inflasi (INF)

Merupakan perkembangan tingkat inflasi yang terjadi di lima negara ASEAN selama tahun 2007 - 2017. Dalam penelitian ini menggunakan tingkat infasi yang menunjukkan besarnya harga - harga secara umum pada periode waktu tertentu secara tahunan. Satuan variabel ini adalah persen.

\section{B. Populasi dan Sampel}

Populasi dalam penelitian ini adalah negara ASEAN yaitu Indonesia, Malaysia, Singapura, Thailand, Filipina, Vietnam, Brunei Darussalam dan Kamboja selama periode penelitian 2007 sampai dengan 2017 Menggunakan variabel dependen yang digunakan adalah pertumbuhan ekonomi (G), sedangkan variabel independennya adalah trade openness (TO), Foreign Direct Investment (FDI), pengeluaran pemerintah (GOVEX) dan inflasi (INF).

\section{Metode Analisis}

Metode analisis yang digunakan dalam penelitian ini adalah model regresi data panel dengan menggunakan Fixed Effect Method (FEM). Alat analisis yang digunakan Microsoft Excel 2013 dan software Eviews 9. Persamaan dalam model penelitian ini dapat ditulis sebagai berikut:

$$
\operatorname{Ln}(G)_{i t}=\beta 0+\beta 1 \operatorname{Ln}(\text { TO })_{i t}+\beta 2(F D I)_{i t}+\beta 3 \operatorname{Ln}(\text { GOVEX })_{i t}+\beta 4(I N F)_{i t}+e_{i t}
$$

Keterangan :

$$
\begin{array}{ll}
\text { LnGDP } & \text { Laju Pertumbuhan Ekonomi } \\
\text { LnTO } & =\text { Keterbukaan Perdagangan } \\
\text { FDI } & =\text { Foreign Direct Investment } \\
\text { LnGOVEX } & =\text { Pengeluaran Pemerintah } \\
\text { CPI } & =\text { Tingkat Inflasi } \\
& =\text { error term } \\
\mathrm{e}_{i t} & =\text { intersep } \\
\beta 0 & =\text { Koefisien variabel bebas }
\end{array}
$$

\section{HASIL DAN PEMBAHASAN}

Analisis data dilakukan dengan metode Fixed Effect Method (FEM). Data yang diolah adalah data panel dengan objek penelitian negara ASEAN yaitu Indonesia, Malaysia, Singapura, Thailand, Filipina, Vietnam, Brunei Darussalam dan Kamboja dalam kurun waktu tahun 2007 - 2017. Analisis ini untuk melihat pengaruh keterbukaan ekonomi terhadap pertumbuhan ekonomi. Berdasarkan hasil estimasi regresi data pada tabel dibawah, maka diperoleh persamaan sebagai berikut:

\section{$(G)_{i t}=-36.50762+0.053526(\text { TO })_{\text {it }}+0.553190(F D I)_{i t}+1.269859 \operatorname{Ln}(G O V E X)_{i t}$} $+0.065060(\text { INF })_{\text {it }}+\mathrm{e}_{\mathrm{it}}$ 
Jurnal Dinamika Ekonomi Pembangunan

https://ejournal.undip.ac.id/index.php/dinamika_pembangunan/index

Hasil Estimasi Regresi Data Panel Fixed Effect Method

\begin{tabular}{|l|l|l|l|l|}
\hline \multicolumn{1}{|c|}{ Variabel } & Koefisien & $\begin{array}{c}\text { Std. } \\
\text { Error }\end{array}$ & T-stat & Prob \\
\hline TO & 0.053526 & 0.013975 & 3.830099 & 0.0003 \\
\hline FDI & 0.553190 & 0.101462 & 5.452191 & 0.0000 \\
\hline LN_GOVEX & 1.269859 & 0.864380 & 1.469098 & 0.1459 \\
\hline INF & 0.065060 & 0.036039 & 1.805280 & 0.0750 \\
\hline C & -36.50762 & 20.73064 & -1.761046 & 0.0823 \\
\hline F-stat & 12.248 & & & \\
\hline Prob (F) & 0.0000 & & \\
\hline R-square & 0.6393 & & & \\
\end{tabular}

Sumber: Hasil Pengolahan Data dengan Eviews9

Uji statistic F menunjukkan apakah seluruh variabel independen dalam hasil penelitian memiliki pengaruh secara bersama-sama terhdap variabel dependen. Hasil estimasi pengaruh Trade Openness (TO), FDI, Pengeluaran Pemerintah (Govex), dan inflasi (INF) terhadap pertumbuhan ekonomi (G) dengan menggunakan taraf keyakinan $95 \%(\alpha=5 \%)$, dan diperoleh degree of freedom for numerator (dfn) sebesar 4 dimana didapat dari rumus k-1 = 5-1 serta diperoleh degree of denominator (dfd) sebesar 83 dimana hasil tersebut diperoleh dari rumus $\mathrm{n}-\mathrm{k}=88-5$, sehingga diperoleh F tabel sebesar 2.48. Dari hasil estimasi diatas nilai F-statistik sebesar 639.98 dengan probabilitas 0.000 dengan $\mathrm{F}$ tabel sebesar $2.48<12.248$ dengan taraf keyakinan 95\% 0.05>0.000 maka dapat dikatakan bahwa variabel independen (TO, FDI,GOVEX, INF) bersama - sama berpengaruh terhdapa variabel dependen (G).

Uji $t$ digunakan untuk mengetahui pengaruh variabel independen secara individual/parsial terhadap variabel dependen, dengan asumsi variabel independen lainnya konstan. Selanjutnya dalam mengestimasi t-hitung dapat membandingkannya dengan t-tabel atau bisa juga dengan melihat nilai probabilitasnya. Dengan taraf keyakinan $95 \%(\alpha=5 \%)$, didapat nilai degree of freedom for numerator (dfn) sebesar 4 dimana didapat dari rumus k-1 = 5-1 serta diperoleh degree of denominator (dfd) sebesar 83 dimana hasil tersebut diperoleh dari rumus $\mathrm{n}-\mathrm{k}=88-5$ maka diperoleh nilai t-tabel sebesar 1.66342. Apabila nilai t-hitung $>$ t-tabel dapat dikatakan variabel independen berpengaruh secara signifikan terhadap variabel dependen. Berdasarkan hasil estimasi, variabel TO berpengaruh positif dan signifikan terhadap G, dengan nilai t-hitung>t-tabel (3.830099>1.66342), variabel FDI berpengaruh positif dan signifikan terhadap GDP, karena nilai t-hitung>t-tabel (5.452191>1.66342), Variabel GOVEX berpengaruh positif tidak signifikan terhadap $\mathrm{G}$, karena nilai t-hitung < t- tabel $(1.469098<1.66342)$. Variabel INF berpengaruh positif dan tidak signifikan terhadap GDP, karena nilai t-hitung < t-tabel $(1.805280<1.66342)$.

Nilai koefisien determinasi dalam model ini sebesar 0.639 yang berarti $63 \%$ keragaman variabel dependen mampu dijelaskan oleh keragaman variabel indepeden. Sementara itu sisanya dijelaskan oleh variabel lain yang tidak dimasukkan ke dalam model penelitian. Nilai koefisien determinasi tersebut menunjukkan bahwa model penelitian ini baik digunakan. 


\section{KESIMPULAN}

\section{A. Kesimpulan}

Berdasarkan hasil penelitian mengenai analisis keterbukaan ekonomi terhadap pertumbuhan ekonomi, maka kesimpulan yang dapat dipaparkan adalah sebagai berikut:

1. Keterbukaan perdagangan atau trade openness sebagai variabel independen pertama berpengaruh signifikan terhadap pertumbuhan ekonomi di ASEAN. Variabel ini yang menggambarkan keterbukaan ekonomi ini dibuktikan mempunyai pengaruh untuk pertumbuhan ekonomi.

2. FDI atau foreign direct investment sebagai variabel independen berpengaruh signifikan terhadap pertumbuhan ekonomi di ASEAN. Variabel ini yang menggambarkan keterbukaan ekonomi dari sisi finansial ini dibuktikan mempunyai pengaruh untuk pertumbuhan ekonomi.

3. Pengeluaran pemerintah dalam penelitian ini tidak memiliki pengaruh dalam pertumbuhan ekonomi di era keterbukaan. Hal ini diduga karena pengalokasian pengeluran pemerintah ASEAN belum efektif sehingga menyebabkan kelambanan pengaruh terhadap pertumbuhan ekonomi di ASEAN.

4. Inflasi berpengaruh positif dan tidak signifikan terhadap pertumbuhan ekonomi di ASEAN. Disebabkan karena negara-negara di kawasan ASEAN berhasil menekan inflasinya pada tingkat yang rendah yaitu dibawah $10 \%$. Oleh karena itu, walaupun tingkat inflasi tidak berpengaruh terhadap pertumbuhan ekonomi, tetapi apabila dibiarkan begitu saja hingga terjadi kenaikan tingkat inflasi yang tinggi bahkan sampai terjadi hiperinflasi, maka peristiwa tersebut akan mempengaruhi perekonomian sehingga pertumbuhan ekonomi menjadi negatif atau menurun.

\section{B. Saran}

Berdasarkan hasil penelitian ini maka saran yang hendak disampaikan adalah sebagai adalah diharapkan mampu menganalisis berdasarkan periode jangka pendek dan jangka panjang untuk melihat gambaran secara jelas mengenai dampak keterbukaan ekonomi dalam jangka pendek dan jangka panjang. Selain itu dapat pula dianalisis dengan menambahkan indikator keterbukaan lainnya seperti liberalisasi finansial (tingkat suku bunga riil), liberalisasi modal (net capital inflows) dan lain lainnya.

\section{REFERENCE LIST}

Adhikary, B. K. 2011. FDI, Trade Openness, Capital Formation, and Economic Growth in Bangladesh: A Linkage Analysis. International Journal of Business and Management, 6(1), 16-28.

Adrian Sutawijaya dan Zulfahmi.2007 "Pengaruh ekspor dan Investasi Terhadap Pertumbuhan Ekonomi Indonesia tahun 1980-2006," Jurnal Organisasi dan Manajemen, Volume 8, Nomor 2, September 2007.

Anwer, S. M. dan Sampath, K. R. 1999. Investment and Economic Growth.

Presented at Wstern Agricultural Economics Association Annual Meeting. Fargo. ND 
Azid, M. T. T. 2015. The Relationship between International Trade Openness and Economic Growth in the Developing Economies: Some New Dimensions. China: Exeter University.

Baltagi, B. H. 2005. Econometric Analysis of Panel Data (3rd ed.). New York: John Wiley \& Sons.

Barro, R. J.2003. Determinants of Economic Growth: A Cross-Country Empirical Study. Cambridge University.

Bibi, S., and Rashid, H. 2014. Impact of Trade Openness, FDI, Exchange Rate and Inflation on Economic Growth: A Case Study of Pakistan. International Journal of Accounting and Financial Reporting. Vol. 4, No.2

BKF Kemenkeu. 2013. Laporan Hasil Kajian, "Free Trade Agreement (FTA) dan Economic Partnership Agreement (EPA), dan Pengaruhnya terhadap Arus Perdagangan dan Investasi dengan Negara Mitra Jilid 2". Jakarta: Tim Kajian Pusat Kebijakan Regional dan Bilateral 2013.

Blanchard, Oliver. 2004. Macroeconomic 4 Edition. Pearson Prentice Hall. New Jersey.

Chang, C. C., \& Mendy, M. (2012). Economic growth and openness in Africa: What is the empirical relationship? Applied Economics Letters, 19(18), 1903-1907.

Damodar N., Gujarati dan Dawn C. Porter. 2012. Dasar-dasar Ekonometrika Buku 2. Edisi 5. Raden Carlos Mangunsong (penj.). Jakarta: Salemba Empat

Deliarnov. 2012. Perkembangan Pemikiran Ekonomi - Edisi ke 3. Jakarta: Divisi Buku Perguruan Tinggi, PT Raja Grafindo Persada

Denty, Octavianingrum. 2015. Analisis Pengaruh Investasi, Tenaga Kerja, dan Tingkat Pendidikan terhadap Pertumbuhan Perekonomian di Daerah Istimewa Yogyakarta. Skripsi. Universitas Negeri Yogyakarta. Yogyakarta.

Dominick, Salvatore. 1997. Ekonomi Internasional, alih bahasa oleh Haris Munandar edisi 5 cetak 1. Jakarta: Erlanga

Dreher, A. 2006. The influence of globalization on taxes and social policy: An empirical analysis for OECD countries. European Journal of Political Economy, 22(1), 179-201.

Eriksson, Clas. 1995. Economic Growth with Endogenous Labaour Supply. European Journal of Political Economy. Vol 12. Elsevier

Fathoni, Rinaldy Achmad Roberth, dkk. 2017. Pengaruh Ekspor Intra-ASEAN dan FDI Intra-ASEAN Terhadap Pertumbuhan Ekonomi Negara ASEAN (Studi Pada Negara Indonesia, Malaysia, Singapura, dan Thailand Tahun 2006-2015). Jakarta: Jurnal Administrasi Bisnis Volume 45 Nomor 1 April 2017.

Gupta, S., Clements, B., \& Tiongson, E. (1998). Public Spending on Human Development. Finance and Development.

Herawati, Wahyun.2016.Analisis Pengaruh Keterbukaan Ekonomi Terhadap Pertumbuhan Ekonomi di Indonesia Tahun 1980-2013. Bogor: Fakultas Ekonomi. 
Jhingan, M.L., 2003, Ekonomi Pembangunan dan Perekonomian, Jakarta : PT. Raya Grafindo Persada.

Juanda, Bambang., 2009, Metodologi Penelitian Ekonomi dan Bisnis. IPB Press. Bogor.

Kakar, Z., and Khiji, A.B.2011. Impact of FDI and Trade Openness on Economic Growth: A Comparative Study of Pakistan and Malaysia. Theoretical and Applied Economics Volume 18 No 11.

Kawai, Masahiro, dan Peter J. Morgan. 2013. Long Term Issues for Fiscal Sustainability in Emerging Asia. ADBI Working Paper 432.Tokyo: Asian Development Bank Institute.

Kilic, Rehim.2002.Absolute and Comparative Advantage: Ricardian Model. Department of Economics, Marshall Hall

Krugman, Paul dan Obstfeld, Maurice, 2004. Ekonomi Internasional Teori dan Kebijakan Harper Collins Publisher. Ahli Bahasa. DR. Faisal H. Basri, SE MSc, Jakarta: PT Indeks Kelompok Gramedia.

Lanza, V. 2012. The classical approach to capital accumulation. Umea University, $2-57$.

Lauridsen, Jorgen T., Fatma Zeren, and Ayse Ari. 2013. A spatial panel data analysis of crime rates in EU. Discussion Papers on Business and Economics, No. 2/201.

Lubis, Pardamean Dan Salman Bin Zulam. 2016. Analisis Faktor-Faktor Yang Memengaruhi Permintaan Investasi di Indonesia. Jurnal Perspektif Ekonomi

Darussalam Volume 2 Nomor 2.

Maharani, Kurnia dan Isnowati, Sri. 2014. Kajian Investasi, Pengeluaran Pemerintah, Tenaga Kerja dan Keterbukaan Ekonomi Terhadap Pertumbuhan Ekonomi di Provinsi Jawa Tengah. Jurnal Bisnis dan Ekonomi.

Mankiw, N. G. 2007. Makroekonomi (6th ed.). Jakarta: Erlangga.

Masoud, Najeb. 2014. A Contribution to the the Theory of Economic Growth: Old and New. Journal of Economics and International Finance. Vol 6 (3).

Marbun, Efran. 2018. Pengaruh Trade Openness,Foreign Direct Investment dan Penanaman Modal Dalam Negeri Terhadap Gross Domestic Product

(GDP) Indonesia Tahun 1980-2016. Lampung: Universitas Lampung

Marzuki, Usman. 1989. Pasar Modal Sebagai Piranti untuk Mengalokasi Sumberdaya Ekonomi Secara Optimal Management \& Usahawan Indonesia. No. 10 Thn XVIII.

Bose, Niloy. 2007. Public Expenditure and Economic Growth: A Disaggregated Analysis For Developing Countries. The Manchester School Vol 75 No. 5 September 2007. University of Manchester And University Of Wisconsin-Milwaukee.

Nopirin.2014. Pengantar Ilmu Ekonomi Mikro-Makro. Yogyakarta: BPFEYogyakarta

Nowbutsing, B. M. 2014. The impact of openness on economic growth: Case of Indian Ocean Rim countries. Amerika: Journal of Economics and Development Studies.

Nurjaka, Asep Oman.2002. Intisari Ekonomi. Bandung: Pustaka Setia. 
Palasari, Rr. Suci.2015.Pengaruh Ekspor, Impor, Tingkat Inflasi dan Tingkat Suku Bunga Terhadap Nilai Tukar Rupiah. Malang: Universitas Islam Negeri Maulana Malik Ibrahim.

Pramasty, D. E. \& L. R. (2015). Detreminasi Pertumbuhan Ekonomi di Tujuh Negara ASEAN Periode Tahun1996-2013. Media Ekonomi, 23(2), 107120.

Prijambodo, B. 1995. Teori Pertumbuhan Endogen: Tinjauan Teoritis Singkat dan Implikasi Kebijaksanaannya. Perencanaan Pembangunan, No. 03, 664-82

Purwanto, T. 2011. Dampak Keterbukaan Perdagangan terhadap Pertumbuhan Ekonomi di Negara-Negara ASEAN+3. Bogor: Repository IPB.

Riyad, M. 2012. Faktor-Faktor Yang Mempengaruhi Pertumbuhan Ekonomi Di Enam Negara Asean Faktor-Faktor Yang Mempengaruhi Pertumbuhan Ekonomi Di Enam Negara Asean. Jakarta: Universitas Indonesia

Romer, D. 1993. Trade Openness and Inflation: Theory and Evidence. Quarterly Journal of Economics, CVIII(4), 869-903.

Samuelson, Paul A dan Nordhaus, William D.2001. Ilmu Makro Ekonomi.Jakarta: PT. Media Edukasi.

Simorangkir, I. (2006). The openness and its impact to Indonesian economy: A SVAR approach. Education and Studies, Bank Indonesia, Indonesia, 223260.

Sinnathurai Vijayakumar. 2013. An Empirical Study on the Nexus of Poverty, GDP Growth, Dependency Ratio and Employment in Developing Countries. Jurnal of Competitiveness. Vol. 5. Issue 2, pp 67-82, June 2013.

Sugiyono. 2014. Metode Penelitian Pendidikan Pendekatan Kuantitatif, Kualitatif Dan R\&D. Bandung: Alfabeta.

Sukirno, S. 2013. Makroekonomi: Teori Pengantar (3rd ed.). Jakarta: Rajawali Pers.

Suliswanto, M. S. W. 2010. Globalization And Gross Domestic Product Construction In Asean. Economic Journal Of Emerging Markets, 2, 155-167.

Suparmoko. 2000. Keuangan Negara: Teori dan Praktek. BPFE-Yogyakarta. Hal 4,44-45

Tan, Syamsurijal.1998. Esensi Ekonomi Internasional. Jakarta: Ghalia Indonesia

Tedy Herlambang, et al. 2002. Ekonomi Mikro : Suatu Pendekatan Praktis. Jakarta: Gramedia Pustaka Utama.

Todaro, Michael P. dan Stephen C. Smith. 2006. Pembangunan Ekonomi (edisi kesembilan) Jakarta: Erlangga

Wattanakul, Thanet.2010.Thailan's Openness and Implication for Economics and Trade Policy: an Econometric Study.

Winantyo, R. 2008. Masyarakat Ekonomi ASEAN (MEA), 2015: Memperkuat Sinergi ASEAN di tengah Kompetisi Global. Jakarta: Elex Media Komputindo.

Yanikkaya, Halit. 2003. Trade openness and economic growth: A cross-country empirical investigation. Journal of Development Economics 72 (1): 57-89. 